\title{
Reflections on Individual Personal Values in the Budgetary Slack Phenomenon
}

\author{
PUTU YUNARTHA PRADNYANA PUTRA* \\ FARAH NISA UL ALBAB \\ CHRISTOPHER CLARK ADITYA SWARA
}

Universitas Gadjah Mada

\begin{abstract}
Research and theory on the role of personal values in morality have received significant attention in the last years. In this study, we observe the tendency of individuals acting within organizations to create budgetary slack given their personal values and social reality. Specifically, we interview with the four undergraduate students in Accounting. We observe the ethical dilemma of the students as a representative of youth who ever involved in the budget-setting process. Recent studies in empathy-related responses to the individual ethical dilemma are also discussed. We find that all the participants have different responses to slack the budget after being pressured by their social environment. All the participants tend to create a budget slack by adding unexpected costs in their budgets. They use the "relativist" ideology and feel a sense of empathy towards the sustainability of their organization. However, the participants still prioritize their rationality over the social reality concerning the budgetary slack phenomena. The results suggest that personal values and social reality play a role in determining how individuals should react to the moral reasoning of budgetary slack.
\end{abstract}

Keywords: Personal Values, Social Reality, Budgetary Slack, Ethical Dilemma

Intisari: Penelitian dan teori terkait dengan peran nilai-nilai personal pada moralitas individu telah menjadi perhatian banyak peneliti dalam beberapa tahun terakhir. Studi ini ingin mengamati kecenderungan individu di dalam organisasi untuk menciptakan budgetary slack berdasarkan nilai-nilai personal dan realita sosial yang dimiliki. Secara spesifik, studi ini meliputi wawancara kepada empat mahasiswa sarjana di bidang Akuntansi. Studi ini juga mengamati dilema etis mahasiswa sebagai perwakilan pemuda yang pernah terlibat dalam proses penyusunan anggaran. Hasil penelitian terbaru terkait respon empati individu terhadap dilema etis juga dibahas dalam studi ini. Studi ini menemukan bahwa semua partisipan memiliki tanggapan yang berbeda untuk melakukan budgetary slack setekah diberikan tekanan oleh lingkungan dan sosial mereka. Para partisipan cenderung menggunakan ideologi "relativist" dan berpedoman pada empati terhadap keberlangusungan organisasi. Bagaimanapun, para partisipan masih memprioritaskan rasionalitas masing-masing jika dihadapkan pada realita sosial terkait dengan fenomena budgetary slack. Hasil studi ini menunjukkan bahwa nilai-nilai personal dan realita sosial memainkan peran

* Corresponding author: putu.yunartha.p@mail.ugm.ac.id 
penting dalam menentukan bagaimana individu harus bereaksi terhadap penalaran moral terkait fenomena budgetary slack.

Kata Kunci: Nilai-Nilai Personal, Realita Sosial, Budgetary Slack, Dilema Etis

\section{Introduction}

The diversity of budgeting phenomena in organizations has been discussed in various studies. Douglas \& Weir (2000) state that bias in budgeting is an essential phenomenon in an organization. Bias in the budgeting process can affect strategic decisions taken by middle-level managers and organizational leaders. This bias in budgeting profit-oriented or non-profit organizations are often referred to as "budgetary slack". The phenomenon of budgetary slack is often associated with agency theory which can cause the optimal allocation of resources of an organization. Previous studies consider the budgetary slack as an organizational issue and behavior. However, ethical issues related to the phenomenon of budgetary slack have not become a research priority in the present day. Maiga \& Jacobs (2008) states that organizational members tend to be opportunistic regarding the use of budget information that may cause conflict with organizational norms and individual professionalism. This condition indicates that the budgetary slack phenomenon is related to various moral dilemmas between individuals and organizations.

The non-optimal allocation of resources in an organization or company is an indication of loss for stakeholders Based on identification result shows that the phenomenon of adverse budgetary slack can be seen as an ethical issue, the analysis of ethical dilemmas arising from this phenomenon is needed. Douglas \& Wier (2000) explain that the ethical dilemma in the phenomenon of budgetary slack is fulfilled by moral components which include consideration of one's actions to others. In other words, individuals in an organization will be guided by certain ethical positions and tend to be different from other individuals.

Various literature has discussed participatory budgeting from a strategic and economic perspective. Hobson et al. (2011) discuss the importance of a description of 
moral aspects in the budgetary slack phenomenon. This moral picture can be obtained by creating a conflict between individual economic interests towards social norms such as honesty and responsibility. The study also examined several personal values related to individual moral reasoning related to the budgetary slack phenomenon. One of the personal values that have been successfully tested is "empathy" of every individual in the organization. Eisenberg (2000) sees empathy as not always having a perspective on others. Empathy is more regarded as a result of individual cognitive processes that can be grouped into sympathy, personal distress or both. This grouping is a moral reflection of the dilemma experienced by someone who is participating in ethical or unethical actions. The study conducted by Hobson et al. (2011) succeeded in identifying that individuals with high empathy measures tend to consider the budgetary slack phenomenon into groups unethical actions. The results of the study also state that financial incentives can shape moral views in organizational budgeting, but personal values determine the individual response to these moral views. Based on the theory and empirical testing that has been done, this article wants to identify the relationship between personal values towards the moral reasoning of individuals in organizations related to the budgetary slack phenomenon.

This article also seeks to identify individual intentions to act ethically or unethically based on social or organizational reality. The reality of the organization is a factor that can be related to individual moral reasoning in the organization when facing the budgetary slack phenomenon. The reality of the organization shows the verticalization of the class between leaders and employees. The leader determines the direction of the organization and makes strategic decisions, while the employee obeys every command and assignment given by the leader. The interesting thing is that the tendency of orders and assignments of leaders can disrupt employee personal values. Milgram (1963) considers that leaders often act on behalf of compliance so that employees can follow their personal goals. Individuals who act as employees will tend to do the assignment because they think that the order given has a purpose for the common interest. This condition is supported by the research of Benjamin \& Simpson (2009) which states that political situations and the diversity of the existence of classes 
in organizations cause the psychological research paradigm tends to form hypotheses based on environmental factors and not from the individual's internal side.

Several factors can moderate the relationship between personal value to individual ethical decision choices. Glover et al. (1997) stated that demographic factors are related to the intensity of morality possessed by individuals. This article wants to identify the role of age characteristics in ethical decision making related to the budgetary slack phenomenon. Specifically, this article wants to analyze the personal values that exist in youths in responding to ethical issues. Basically, young people are often described as individuals who want to achieve a lot of achievements and be recognized by the people around them. The selection of youth as the subject of this article is consistent with the results of Glover et al. (1997) which states that work experience and age maturity correlates with the level of ethical behavior in the organization. Furthermore, the study also explained that individuals who want to achieve achievement in the organization would tend to make ethical choices when the moral intensity in the organization is not classified as extreme (very low moral intensity or very high moral intensity). This shows that there are ethical dilemmas in youth when it comes to dealing with the budgetary slack phenomenon in a dynamic environment. Based on the background that has been conveyed, there are two big questions in this study as follows:

1. How do youths apply empathy values in shaping moral reasoning related to the budgetary slack phenomenon?

2. How do individuals make decisions when facing ethical dilemmas between personal interests and social reality?

\section{Theoretical Framework}

\subsection{Budgetary Slack}

Organizations carry out various activities for the continuity of the organization or commonly referred to as "going concern". However, the fact is that not all activities are going well and perfectly. The process of an imperfect organization in allocating resources can lead to the budgetary slack phenomenon (Onsi, 1973). Traditionally, 
budgetary slack is seen as an organizational and behavioral issue (Douglas \& Wier, 2000). This is because budgetary slack is related to ethical or unethical actions of an accountant profession. Dunk \& Nouri (1998) state that slack occurs when the budgeting process is done by understating income and productive capabilities intentionally and/or overestimating costs and allocating the required costs. Onsi (1973) provides a basic explanation that the amount of slack depends on company profitability, sales growth as well as several other behavioral factors.

The manager of an organization does budgetary slack for various reasons and conditions. According to Onsi (1973), the first reason that is often used is as a method to achieve budget targets and show annual profit growth. This can be related to the pressure given by top management in an organization. Another reason that can cause the budgetary slack phenomenon is the desire of managers to take refuge in uncertainty in the future. Furthermore, Onsi (1973) states that as many as $80 \%$ of managers bargain in estimating various types of costs (production costs, estimated sales volumes and sales prices) to create slack in the company's operating budget. In other words, the manager's consideration in conducting budgetary slack does not only come from the profit growth factor but also based on the estimation of various costs.

Some studies state that budget participation and asymmetry information influence budgetary slack (Dunk, 1993; Dunk \& Nouri, 1998). Asymmetry information occurs when subordinates have more information than their superiors (Dunk, 1993). Although it has a positive impact on individuals and organizations, the method of participation also has a negative impact. Dunk (1993) found that subordinate participation in budgeting allowed slack to occur when asymmetry information occurs. The results of this study also become the basis for understanding the budgetary slack phenomenon when high-pressure factors arise on the budget. In other words, subordinate participation can influence the creation of budgetary slack if followed by other factors in the form of pressure on the budget. The results of the investigation by Dunk \& Nouri (1998) explain that another factor that can be related to the budgetary slack phenomenon is the ambiguity of the role of organizational members and interactions in the organizational environment. 
Budgetary slack is essential for lower level managers because it is directly related to compensation schemes. Adi \& Mardiasmo (2002) explain that lower-level managers will try to create slack in the budget to obtain awards from the organization. Dunk (1993) reinforces this condition by arguing that the main argument for the efforts of lower-level managers in creating budgetary slack is to increase the purpose of the reward. This condition indicates that each member of the organization has the opportunity to influence the budget formulation process. However, this condition assumes that the level of participation of organizational members is high. The low level of participation towards the budget indicates that the organization can be controlled from external parties

The budgetary slack phenomenon can also be related to the influence of social pressure or obedience pressure. Young (1985) states that social pressure can affect the occurrence and scope of the creation of budgetary slack. Davis et al. (2006) found that compliance pressure can encourage managers to create budgetary slack. The results of this study are increasingly interesting with the finding of another fact that managers who have carried out budgetary slack tend to be less responsible for these actions. Davis et al. (2006) used four individual characteristics as moderating variables, as follows: (1) professional commitment; (2) impression management; (3) perceived pressure strength; and (4) perceived decision difficulty. The test in this study was conducted using the experimental method by classifying the impact of obedience pressure on managers into three categories, as follows: (1) no obedience; (2) total obedience; and (3) zone of compromise. Research illustration of Davis et al. (2006) can be shown by Picture 1 .

Picture 1.

Category of Pressure Compliance with Budgetary Slack Phenomenon

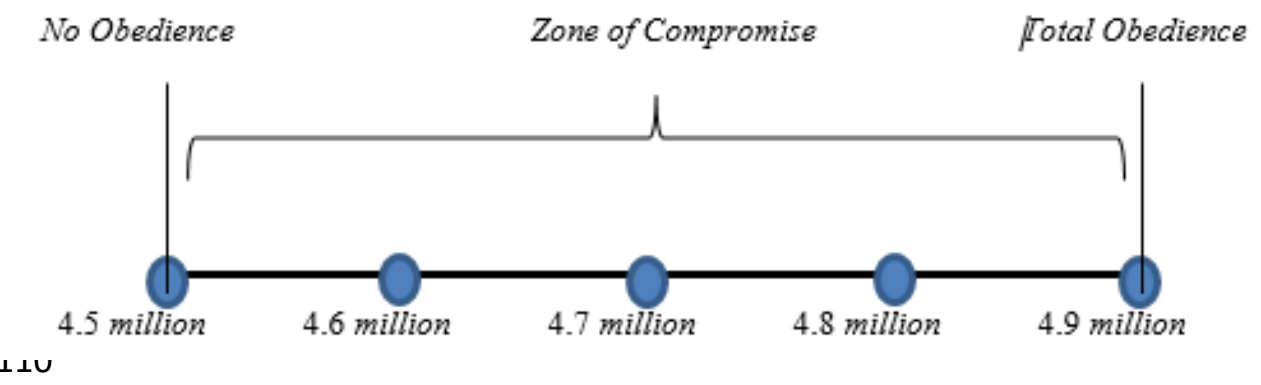


The picture shows that managers can be categorized into the no obedience group if they choose a budget of USD 4.5 million after the compliance pressure is given. In other words, managers in the group continue to choose budgets following company policies even though their superiors have put pressure on them. Zone of compromise is a group of managers who choose a budget between USD 4.5 million and 4.9 million after pressure from superiors is given. This category is exciting to investigate because the managers in it experience various types of conflicts and ethical dilemmas. Total obedience is the last category where managers choose a budget of USD 4.9 million after being pressured by their superiors. The research method of Davis et al. (2006) is one of the researchers' guidelines for identifying social influences on ethical decision making in organizations.

\subsection{Budgetary Slack dan Personal Values}

The concept of budgetary slack is widely discussed based on its relationship with agency theory. These discussions show the scientific dynamics that previously assumed that budgetary slack was only related to organizational issues and behavior. The relationship between the concept of budgetary slack and the behavioral aspects of the budget compiler can indicate the ethical dimension. Douglas \& Wier (2000) expanded the study of budgetary slack by analyzing the ethical dimensions of budgetary behavior. The results of these studies indicate that an ethical position can explain their behavior to create or not create a slack budget.

Douglas \& Weir (2000) remind the academics in the accounting field that the ethical dimension has strong implications for policies on companies and the government environment. However, this study has not specifically explained the scope of policy that management should take when facing budgetary slack behavior. Hobson et al. (2011) complement the previous research by adding a test of management's moral judgment when making a budget slack. This test was conducted in an experimental form on participatory budgeting by adding honesty expectations toward 
the budget. Hobson et al. (2011) well explain that financial incentives and personal values play an essential role in determining the moral form in a budget slack condition. This shows that the ethical position of management when facing budget slack is related to the management's perception of good or bad morals.

Researches related to ethical dilemmas faced by management in dealing with budgetary slack have not discussed the factors of management's personal values in shaping moral reasoning. However, the personal values of each tend to be different. Maiga \& Jacobs (2008) conducted a study that examined the ethical judgment of each company manager who faced slack budget conditions. This study successfully identified that ethical judgment moderates the relationship between budget participation and budget slack. Identification of ethical judgment by managers is a valuable source of information for principals in these organizations in creating ethical norms or rules specifically related to the phenomenon of budgetary slack. Maiga \& Jacobs (2008) study has several limitations related to the diversity of business conditions. Various characteristics that can affect business situations such as (1) age, (2) gender, and (3) education, are not considered in the study. This study also uses the assumption that organizational control is carried out properly so that each member of the organization is expected to behave following organizational values. In real conditions, organizational control can vary according to the size of the organization, culture, and stakeholders involved.

The use of agency theory in the budgetary slack phenomenon is a very interesting condition to investigate. Luft (1997) has identified this situation through research results that show that personal interests tend to disappear when organizational goals are considered ethical decisions by members of the organization. Investigation in this study also shows that everyone has a diverse view of behaviors that are by ethical preferences such as honesty or justice. This indicates that personal values have a strong relationship with one's moral reasoning. Hobson et al. (2011) criticized previous studies which stated that personal values are only related to aspects of one's wealth. This criticism is supported by the moral concept of the philosophy and moral psychology that emphasizes personal values that are comprehensive and 
individualistic. Also, Glover et al. (1997) suggest that the impact of age or work experience is huge on ethical decision making in organizations. This indicates that personal values can develop along with one's maturity process. These assumptions that underlie the intention of this article to analyze further related to the relationship of individual personal values which tend to be a youth with the creation of budgetary slack in the organizational environment.

Some studies show that personal values can influence moral judgment regarding unethical activities. Jones (1991) explains that personal factors can differ between individuals, especially those related to moral issues. In other words, the case of budgetary slack can be viewed differently by each in an organization. Youth's view of the model of ethical decision making is very interesting to study because it includes dynamic moral issues. Forsyth (1992) examines personal moral philosophies which are considered to influence the moral judgment of individuals towards ethical business practices. This test covers the philosophy of subjectivists who assess that all individuals should act following their own personal interests rather than having to focus on producing positive benefits for society in general. This shows that individuals in the organizational environment can adhere to idealism or relativism which will determine moral judgment on moral issues. However, this study also concludes that the impact of personal moral philosophies towards moral judgment depends on social conditions. In other words, the moral judgment made by individual youths is dynamic because young individuals tend to have the intention to socialize and build certain relationships within the organization.

Individuals can build moral reasoning before generating moral judgment. Glover et al. (1997) stated that a significant part that shapes moral reasoning is the individual's concern for others and the individual's concern for the impact of his actions on social life. Deigh (1995) stated that concern as a personal value in the form of empathy. This article explains that empathy does not only respond to someone's perspective or feelings but also understands the reasons for the person to do specific actions. In other words, empathy is an embodiment of the individual's view of other individuals who see things outside the egocentric perspective. Eisenberg (2000) states 
that emotions play an essential role in shaping individual morality which includes responses in the form of empathy. The difference in the individual's emotional dimension in the organization will be related to the empathy response it has. Identification of emotional differences between individuals is needed to define one's empathic capacity (Deigh, 1995). Based on the support of various theories and concepts in moral philosophy that have been described, this article predicts that personal values in the form of empathy are related to youth moral reasoning to create budgetary slack.

\subsection{Budgetary Slack and Social Reality}

Basically, vertical relations between humans will always be formed along with the interactions that they do. Relationships between humans in an organization or company can be seen from the agency point of view. Based on this concept, a leader will always give orders to his members and the members are expected to fulfill orders even though they often conflict with his conscience. This assumption can underlie the conflicts that often occur in the organizational environment including the phenomenon of budgetary slack.

Several philosophers and thinkers have discussed the reality of the relationship between leaders and their members. One of them is Hannah Arendt through the Banality of Evil phenomenon. She saw the phenomenon of army obedience during World War II. Arendt interviewed a German soldier named Adolf Eichmann about his actions and obligations of war (Arendt, 2006/1963). Arendt concludes Eichmann's actions as follows:

"He was not inherently evil, but merely shallow and clueless, a 'joiner', in the words of one contemporary interpreter of Arendt's thesis: he was a man who drifted into the Nazi Party, in search of purpose and direction, not out of deep ideological belief" (White, 2008) 
Through an analysis of Eichman's personality, Arendt stated that Eichmann was not a war criminal. According to her, Eichmann didn't realize "what he was doing?" Eichmann's cognitive abilities disappear when he gets command. Eichmann is unable to think from another perspective. The distance between Eichmann and the reality of normal human life causes a decrease in his personal morale.

Based on psychology, research on obedience or obedience was born from Stanley Milgram. He is famous for electric stun experiments and role-playing (Burger, 2009). The purpose of the experiment was to determine the level of obedience by giving questions to 40 Yale University students. In playing the role, there are those who become teachers and students. If the student makes a mistake, he will be electrocuted. Milgram concluded that obedience and obedience of an individual depend on "who gave the order and the assignment?". Milgram saw the legitimacy of the order giver and assignment play a significant role in decision making.

Unlike Milgram, Jerry M. Burger saw the weakness of Milgram's research. In the opinion of Burger (2009), Milgram's research relied on male participants as well. Female participants actually feel more empathy than other participants. Burger (2009) shows that individuals tend to leave the experimental space when they have seen the actions of their friends. Another theory that can be the basis for decision making in the budgetary slack phenomenon is "The Images of Organization" formulated by Gareth Morgan. The theory explains the eight approaches used to view organizations (Morgan, 2006). One of them is a political approach to involving power and interests. Through this research, Morgan (2006) argues that if an individual knows his motivation, this individual can challenge the legitimacy of the organization.

\section{Research Method}

This article aims to obtain information about individual personal values, social reality, and budgetary slack. This article uses a descriptive qualitative approach. The type of data obtained is primary data. This primary data is obtained through interviews with the undergraduate students of the Faculty of Economics and Business Universitas Gadjah Mada as the subject of the study. The researcher applied data collection 
techniques in the form of field research. Field research was carried out to obtain information in depth through data and information directly from the research subjects. The field research method used in this article is an interview. The interview session regarding budgetary slack consists of 6 core questions as follows:

1. Have you ever compiled an organizational budget?

2. What did you do first to make the budget?

3. How do you estimate the detailed costs in the budget? Do you tend to make estimates based on actual prices or exceed actual prices?

4. Have you ever experienced unexpected costs that must be incurred when the program took place, and you did not record these costs in the budget?

5. What do you do to anticipate unexpected costs in the activities that will be carried out?

The next step is to provide a case scenario regarding budgetary slack to participants. The case scenario is based on the study of Davis et al. (2006) which has been adjusted by the researcher. The illustration of the case is as follows:

"Assume that you are a manager of accounting services at A Ltd. A Ltd. is a manufacturing company that produces basic needs such as instant noodles, milk, cooking oil, soy sauce, sauce, and so on."

"When entering the budgeting process for 2019, the company's CEO (Chief Executive Officer) discusses new budgeting policies. The CEO stated that the economy was experiencing a decline lately and causing overhead costs to be made as accurate as possible. The CEO stated that next year's budget must be Rp. 4,5 billion. However, the CEO also argues that the budgeted level of expenditure should adhere to the principle of "challenging but attainable goals".

"At the end of the meeting, A Ltd.'s CFO (Chief Financial Officer) withdrew you and said: "I want you to change the recommendations of Rp.4.5 billion to Rp.4.9 billion like last year." If the current budget is smaller than last year's budget, it will affect the 
bonus of all employees, and this will have an impact on the poor management of the entire division. This is because employee bonuses are calculated based on the accuracy between the budget and realization so that the realization must not exceed the amount previously budgeted."

After the case served to the participants, the researcher will ask how much the budget is recommended by the participants. The choice of budget recommendations are: (1) IDR4.5 billion, (2) IDR4.6 billion, (3) IDR4.7 billion, (4) IDR4.8 billion, and (5) IDR4.9 billion. After the participant chooses, the researcher then asks things related to virtue ethics. These questions are summarized as follows:

1. How do you feel your life is happy? What is your definition of happiness?

2. Have you been depressed? Have you ever felt rushed? Who makes you feel scared?

3. What is a rational action?

4. What do you think of selfishness? What are the terms that describe togetherness?

5. How do you investigate the interests of various parties? Why do you have to care for others?

6. What do you think about collective action against things that are not true?

After conducting the interview, the researcher analyzed the answers of each participant to the questions given by the researcher. The results of the analysis are then grouped into similar sub-themes. The researcher will draw conclusions based on the collected data and analysis.

\section{Discussion}

\subsection{The Opinion of Budgetary Slack}

Budgetary slack can apply by increasing the budget or reducing the income budget. This article refers to the research conducted by Davis et al. (2006) related to the phenomenon of budgetary slack. Participants have been given a case and have chosen the following groups: 
Table 1.

Group of Participant's Budget Total Amount After Given Compliance Pressure to Create a Budgetary Slack.

\begin{tabular}{|l|l|l|}
\hline No & \multicolumn{1}{|c|}{ Responden } & \multicolumn{1}{c|}{ Choices } \\
\hline 1 & Participant 1 & $\mathrm{Rp} \mathrm{4,5} \mathrm{billion}$ \\
\hline 2 & Participant 2 & $\mathrm{Rp} \mathrm{4,9} \mathrm{billion}$ \\
\hline 3 & Participant 3 & $\mathrm{Rp} \mathrm{4,9} \mathrm{billion}$ \\
\hline 4 & Participant 4 & $\mathrm{Rp} \mathrm{4,7} \mathrm{billion}$ \\
\hline
\end{tabular}

Based on the table, it can be identified that the results of participants' choices are diverse. Davis et al. (2006) divided participants into three groups, as follows: (1) total obedience, (2) no obedience, and (3) zone of compromise. This article categorizes participants into the total obedience group when the participants raise the initial budget recommendation of Rp.4.5M to Rp.4.9M as a result of instructions from the superior manager. The no obedience group is a participant who refuses to change the initial budget recommendation, which is equal to Rp. 4,5 M. The zone of compromise is a group of participants who raise the initial budget recommendation of Rp. 4,5 M, but do not reach Rp. 4,9 M according to the superior manager's order.

Table 1 shows that the first participant tends to refuse to change the budget. This is consistent with the description of the no obedience group on Davis et al. (2006) who chose not to increase the budget because they considered the action unethical. Another reason that can underlie participants to refuse to increase the budget is the tendency to comply with company efficiency policies. This is supported by the statement submitted by participant 1 , as follows:

\section{"The consequences are only in bonuses, right?" (Participant 1)}

The statement shows that participant 1 considers company policies to be more critical than bonuses received by each. This is different from participants 2 and 3 who chose a budget recommendation of Rp.4.9 $\mathrm{M}$ so that it was in the total obedience category. This group chooses to adhere to the superior manager's instructions on the grounds of adherence to more senior individuals. Another reason for the total 
obedience group choice is the importance of the bonus percentage for lower level managers. Also, participants considered that the budgeting process would be more straightforward if they were following the previous year's budget. Participant 3 considers that company policies related to the decline of the economy as a whole are not a priority issue. This condition is following the quotation from the interview as follows:

"It depends on what problems that exist in the company. If there is no problem, then the one ordered by the CFO is IDR 4.9 billion. If there are internal company problems, then we choose he Rp. 4,5 billion." (Participant 3)

Participant 4 has chosen the budget of Rp.4.7 M so that it is in the group of the zone of compromise. This group acknowledges the importance of compromising with the situation. Davis et al. (2006) explain that individual compromise by complying with company policies and creating budgetary slack at the same time. This indicates a dilemma or ethical conflict over the decisions taken by these participants. One interview quote that supports these indications is:

"Choose IDR 4, 7. If the based on the perspective of the CEO sought is" how the company performs better, "so I try to be better. If the CFO uses financial calculations that focus on IDR 4.9M, actually only IDR 400 million is needed. I, as a manager, think my boss is not wrong; we only have a different perspective. So, I just chose the middle of it "(Participant 4)

The participants seemed to experience an ethical dilemma, so they tended to choose numbers at the midpoint of budget recommendations. Ethical conflicts experienced by the three groups can vary. The group of compromise zones tends to have a higher ethical dilemma compared to other groups. No obedience and total obedience groups have low levels of conflict because individuals in these groups have been convinced of their actions. In fact, individuals in the total obedience group tend 
to shift the responsibility of their decisions to supervisor managers who provide budget setting instructions.

\subsection{Integration of Personal Values at Budgetary Slack}

Budget is an important part that is inseparable from organizational activities. The four participants in this article are representations of youth who express their experience in compiling an organization's budget directly or indirectly. Participant 1 stated that the budget was made based on last year's budget, but also adjusted to current prices.

"I am using the previous year's budget and current price actualization because there will be inflation, which is the increase in prices from last year" (Participant 1)

Unlike the case with the first participant, the second participant only uses the current price in determining budget estimates.

"The latest price is the most important price" (Participant 2)

Estimates in budgeting must also be based on priorities as an example is the most significant costs needed. This is following the third and fourth participant statements.

"The consideration is that the most important item is being used. For example, in the transportation section, the main consideration when making a budget is the gasoline that will be used." (Participant 3)

The first and third participants make a mark-up on the budget from the actual price. This is following the assumption of Onsi (1973) who argues that the creation of slack is carried out by managers by minimizing income and rising costs. Participants in this article are marking-up the budget by adding the budget amount to the cost item.

"If it close to the event, we will use the current price. Later on, we will make the accountability report which is related to absorption fund. If it is not the same, it will 
affect the next management. If the event is still ages away, it will be marked-up." (Participant 1).

"Usually I will mark-up to 10 percent of the current price. We are doing the mark-up thing to keep it safe. If the reality says that it is like the current price, we will return the remaining change. "(Participant 3$)$

In contrast, the second participant tends to use current prices in making budget estimates.

"I prefer to use the current price" (Participant 2)

Participants in this article are also aware of budget constraints in the organization. This obstacle is about the unexpected costs in the future. This causes the cost budget to become unavailable so the organization will take several alternatives to anticipate these constraints. This was answered in Douglas \& Wier's (2000) study which revealed that supervisor managers would use a budget participation model to reduce aspects of uncertainty in the budgeting process. The first and third participants anticipate unexpected costs by using personal money before asking for reimbursement to the organization.

"I never experienced unexpected costs. Usually from the board of directors telling me to use the committee money first and then I will ask for a reimbursement." (Participant 1)

"The gasoline is filled, then I keep the receipt and then I ask for reimburse, but it is not one hundred percent in returning the change." (Participant 3)

Tending to be different from previous participants, the second participant used the concept of cross-subsidies when unexpected costs occurred. Cross-subsidies are carried out with other divisions if there are funds that have not been absorbed so that the funds can be transferred to cover unexpected costs. 
"I will take funds that have not been absorbed. For example excessive realization in other fields. "(Participant 2)

The budget achievement will be difficult to fulfill when there is pressure from various sides. The emergence of unexpected costs will make it difficult for management to manage the budget. However, management performance will look bad when the budget realization target is not achieved. One of the things that can be done by management so that its performance is seen as good performance is by creating budgetary slack. This phenomenon can occur in private organizations and public organizations. The four participants in this article agreed to include unexpected costs in the budget prepared. The participants made a budget mark-up to reduce the risk of future unexpected things. The interesting thing is when several organizations forbid to include these unexpected costs. The background of this ban is the perception that budget mark-up activities will reduce stakeholder trust. The following interview quotes support the statement of the phenomenon.

"Basically I will list the reserve costs in the proposal. But some people may not include unexpected costs. So that a benchmark is needed for goods needed in various stores. "(Participant 1)

The second participant believed that organizational budgeting must be based on current prices. The interesting thing is that the second participant also stated that unexpected costs really need to be included in the organization's budget. This condition indicates that there are inconsistencies in answers that reflect youth's ethical dilemmas in the budgeting process. Based on an ethical perspective in general, budgetary slack can be related to ethical ideology or individual ethical position (Douglas \& Wier, 2000). Forsyth (1992) revealed that two factors underlie individual ethical ideologies, as follows: (1) relativism, and (2) idealist. This study states that relativist ideology views moral issues by using skepticism on ethical principles. 
On the contrary, idealist ideology views that there are always good consequences of any ethical or unethical actions. The four participants tended to choose to do budgetary slack based on relativist ideology. This is due to their view of the need to do budgetary slack to avoid uncertainty in the future. However, participants admitted that they did not get incentives when doing the budgetary slack. This condition can show that budgetary slack can be seen as ethical behavior or unethical behavior within an organization.

\subsection{Empathy and Budgetary Slack}

Every single person has different personal values that may cause different actions. One of the personal values that can shape individual moral reasoning is an aspect of care. Glover et al. (1997) explained that individual care is carried out not only for others but also for social life. Deigh (1995) emphasizes this by stating that the aspect of caring relates to individual moral reasoning will form empathy.

The four participants tended to have the same level of empathy. This can be seen from the response of the participants who stated that someone needs to have empathy for the environment. The response of the participants was following the results of Luft (1997) 's research which showed that personal interests tended to be replaced by organizational interests when organizational members compared ethical actions with organizational goals.

"Regarding selfishness and concern for the environment, for example when I work in groups in an organization. I tend to consider the priorities of my colleagues to gain an understanding of my coworkers. "(Participant 1)

"I think that knowing our environment is important because we can determine and target our self-performance." (Participant 2) 
"The way to find out about the problem around is by communication and seeing the surroundings. Finding out the problems and facts that occur, by thinking about the environment. "(Participant 3)

The third participant added opinions related to the consideration of being involved in every event in an organization.

"By being involved, I will be relieved to know an organizational problem and get involved in a solution." (Participant 3)

The fourth participant argues that he must care for others because it is based on personal experience.

"For example, when we are in trouble, suppose we do something that is not accepted by others. For example, Advanced Accounting courses have some people who need help, but there are others who don't need them. Everyone has their own reasons, and we must make reasoning whether we agree with others or not. "(Participant 4)

The fourth participant's statement is in accordance with the results of Luft's (1997) study which states that each individual has various views regarding behaviors that are in accordance with ethical preferences. This shows that everyone has their own way of dealing with various situations. The responses of the four participants generally assumed that organizational interests were more important than personal interests. These individuals tend to have a high sense of empathy when organizational interests are a priority. The four participants can take action if an organization has a problem. In other words, one of the things that underlies the participants doing budgetary slack is the presence of participants' empathy for the organization. Participants assume that this is one of the actions that can be taken so that organizational programs can be implemented and shared goals can be achieved. 


\section{4 budgetary slack and social reality}

Basically, youth can demonstrate ethical behavior when facing a decision-making dilemma at the organizational level. Participants in this study have shared their experiences that they can think rationally in their environment. The following interview excerpts can be the basis for the statement:

"I was a subordinate. During my work, I was worried about my supervisor's perceptions, such as my lack of work. "(Participant 1)

"In lectures, I was in a hurry when I got assignments from lecturers. Also, organizational experience also plays a role. "(Participant 2)

"Feeling depressed? Absolutely. The expectation of parents is one of the things that makes me burdened. "(Participant 3)

"I feel worried if I cannot meet the needs or expectations of people who need my help. One of them is this interview process. "(Participant 4)

The four participants showed that they were able to think rationally in every problem they had. Based on the theory of Milgram (1963), each participant has a different answer about "who is worried". The first and second participants answered about the existence of the organization's work and lectures, the third participant prioritized parents, and the fourth participant thought about the presence of people around him (at that time was the research team). This shows that all participants feel responsible and do not underestimate the status and role of the instructor or assignment.

The rationality formed by each participant relates to social reality in their environment. Each participant tries to channel his thoughts about the role of the individual in the goodness of the organization. The following interview quote shows the phenomenon: 
"Through my person, if the community sees a 'role model' from within me, then I will be a role model for the community." (Participant 1)

"There must be an initiator, so I can coordinate on what should I do." (Participant 2)

"I tend to judge 'am I involved in every event?' For example, when there is an accident, I will consider my involvement first. I assume that the knowledge of the problem from every event that occurs will help me in giving a solution and make me relieved. "(Participant 3)

"Judging others, I will rationalize the needs of that person. 'What is the basis for her doing an action? 'For example, if someone steals, we must ask her motivation well. Then, when there are people who have manual answers, then we must understand it first and do not immediately label it negatively. Everyone has their own reasons. Therefore, I have to care. "(Participant 4)

The statement of the four participants was the basis of the discussion that individuals would tend to see the involvement of others before involving themselves. In addition to the aspect of obedience to superiors who have high legitimacy, participants do not want to see other people suffer heavy losses if they are not involved in a problem. Although the ethical position of each participant tends to be different, the rationality formed based on the rationalization of each has to do with the social reality that surrounds it.

\section{Conclusions, Implications, and Limitations of Research}

This research focuses on observing the personal values of individuals and their social reality when facing the budgetary slack phenomenon in an organization. This article shows that the four participants have different responses when given pressure by superiors in the creation of budgetary slack. The four participants tended to do budgetary slack by adding unexpected costs in their budget. This they do base on relativist ideology and empathy for the sustainability of the organization. However, 
these participants still prioritized their respective rationality when facing social reality concerning the phenomenon of budgetary slack.

This research implies that there is an opportunity for managers to incorporate youth personal values into organizational ethical rules. The broad scope of sampling is a limitation of this research and can be a foothold in thinking for further research ideas. The writer hopes that further study can combine quantitative and qualitative methods in observing personal values in the budgetary slack phenomenon in the environment of private organizations and public organizations. Also, the writer hopes that further research will be able to add external factors that can influence individual responses to moral dilemmas such as ethical codes and legal rules related to the phenomenon of budgetary slack.

\section{References}

Adi, H. C., \& Mardiasmo. (2002). Analisis Pengaruh Strategi Institusi, Budaya Institusi, dan Conflict of Interest terhadap Budgetary Slack. Jurnal Ekonomi dan Bisnis Indonesia, Vol.17, No.1, 105-113.

Arend, H. (2006). Eichmann in Jerusalem: A Report On The banality of Evil. London: Penguin Classics.

Benjamin, L., \& Simpson, J. (2009). The power of the situation: The impact of Milgram's obedience studies on personality and social psychology. American Psychologist, 64(1), 12-19. doi:10.1037/a0014077

Burger, J. (2009). Replicating Milgram: Would people still obey today? American Psychologist, 64(1), 1-11. doi:10.1037/a0010932

Davis, S., DeZoort, F. T., \& Kopp, L. S. (2006). The Effect of Obedience Pressure and Perceived Responsibility on Management Accountant's Creation of Budgetary Slack. Behavioral Research in Accounting, Vol.18, 19-35.

Deigh, J. (1995). Empathy and Universalizability. Ethics, Vol.105, No.4, 743-763.

Douglas, P. C., \& Wier, B. (2000). Integrating Ethical Dimensions into a Model of Budgetary Slack Creation. Journal of Business Ethics, Vol.28, 267-277. 
Dunk, A. S. (1993). The Effect of Budget Emphasis and Information Asymmetry on the Relation Between Budgetary Participation and Slack. The Accounting Review Vol. 68 No. $2,400-410$.

Dunk, A. S., \& Nouri, H. (1998). Antecedents of Budgetary Slack: A Literature Review and Synthesis. Journal of Accounting Literature Vo. 17, 72-96.

Eisenberg, N. (2000). Emotion, Regulation, and Moral Development. Annual Review of Psychology, Vol.51, 665-697.

Forsyth, D. R. (1992). Judging the Morality of Business Practices: The Influence of Personal Moral Philosophies. Journal of Business Ethics, Vol.11, 461-470.

Glover, S. H., Bumpus, M. A., Logan, J. E., \& Ciesla, J. R. (1997). Re-examining the Influence of Individual Values on Ethical Decision Making. Journal of Business Ethics, Vol.16, 1319-1329.

Hobson, J. L., Mellon, M. J., \& Stevens, D. E. (2011). Determinants of Moral Judgements Regarding Budgetary Slack: An Experimental Examination of Pay Scheme and Personal Values. Behavioral Research in Accounting, Vol.23, No.1, 87-107.

Jones, T. M. (1991). Ethical Decision Making by Individuals in Organizations: An IssueContingent Model. The Academy of Management Review, Vol.16, No.2, 366-395.

Luft, J. L. (1997). Fairness, Ethics and the Effect of Management Accounting on Transaction Costs. Journal of Management Accounting Research, Vol.9, 199-216.

Maiga, A. S., \& Jacobs, F. A. (2008). The Moderating Effect of Manager's Ethical Judgement On The Relationship Between Budget Participation and Budget Slack. Advances in Accounting, Vol.23, 113-145.

Milgram, S. (1963). Behavioral study of obedience. Journal of Abnormal and Social Psychology, 67(4), 371-378.

Miller, A. (2016). Why are the Milgram Obedience Experiments still so extraordinarily famous- and controversial? In A. Miller (Ed.), The Social Psychology of Good and Evil, Second Edition (pp. 185-223). New York: The Gulford Press.

Morgan, G. (2006). Images of Organization. California: Sage Publications. 
Onsi, M. (1973). Factor Analysis of Behavioral Variables Affecting Budgetary Slack. The Accounting Review Vol. 48 No. 3, 535-548.

White, T. (2008, April 23). What did Hannah Arendt Really Mean By The Banality of Evil. Accessed from: https://aeon.co/ideas/what-did-hannah-arendt-really-mean-by-thebanality-of-evil

Whitfield, S. (1981). Hannah Arendt and the banality of evil. The History Teacher, 14(4), 469477. Accessed from: http://www.jstor.org/stable/493684

Young, S. M. (1985). Participative Budgeting: The Effects of Risk Aversion and Asymmetric Information on Budgetary Slack. Journal of Accounting Research, Vol.23, No.2, 829-842. 
The Indonesian Journal of Accounting Research - Jan, Vol. 22 , No.1, 2019

intentionally blank 